\title{
Innovation of Information and Communication Technology in Teacher Education
}

\author{
Perigai Chukribauty
}

\begin{abstract}
In the realm of pedagogy the manner in which technology is used implies integration. ICT ascertain the efficiency and effectiveness for communication and the devices assist in handling information. The impact of ICT is felt by those teachers who are in use but in the long run it is going to be used by all the teachers for effective teaching learning process. To ensure the fulfilment of integration of ICT in TTIs there is a need for critical analysis in relation to Infrastructure, Administration work, Curriculum transaction, Teachers competency, Capacity-building, Maintenance facility, Evaluation and Research activity. ICTs have an important role to play in changing and modernizing educational systems and ways of innovation in teaching learning process. The application of ICT in the education setting has to be cultivated, promoted and nurtured as new interactive relationships among teachers, learners and technologies are in high demand. It is high time for the teachers to acquire mastery over the technical know how or else the teachers have to face unwanted problems.
\end{abstract}

Keywords: ICT, TTI, NCTE, Infrastructure, Administration work, Curriculum transaction, Teachers competency, Capacity-building, Maintenance facility, Evaluation, Research activity, Innovation

\section{Introduction}

Information and Communication Technologies (ICTs) has radically occupied a vital place in education and training due to its immense utility. The term ICT encompasses the range of hardware (desktop and portable computers, projection technology, calculators, data logging and digital recording equipment), software applications (generic software, multimedia resources) and information systems (Intranet, Internet) available in the teaching institutes (Brannigan, 2010). Hardware and software resources are in day to day use. According to Zhao and Cziko (2001) three conditions are necessary for teachers to introduce ICT into their classrooms: teachers should believe in the effectiveness of technology, teachers should believe that the use of technology will not cause any disturbances, and finally teachers should believe that they have control over technology. There is a need for to understand the potentialities by the teaching community. According to Soyinka [1999:12] the needs for ICT is felt due to the following:

- Use of electronic equipments facilitates dissemination of information

- ICT ensures speedy recording, processing and presenting of information.

- ICT contributes to quick flow of office work.

- ICT facilitates quality work.

ICT ascertain the efficiency and effectiveness for communication and the devices assist in handling information. It teaches us how to change organization and basically how to innovate in our relationship with environment and our competition with other organizations, in order to have an intelligent action with new organizations (Leven and Wadmany, 2008).

Combining all essential elements in the teaching and learning process including technology includes a sense of completeness or wholeness and incorporates the need for integration. In the realm of pedagogy the manner in which technology is used implies integration. They must go beyond information retrieval to problem solving; allow new instructional and learning experiences not possible without them; promote deep processing of ideas; increase student interaction with subject matter; promote faculty and student enthusiasm for teaching and learning; and free up time for quality classroom interaction- in sum, improve the pedagogy (Earle 2002: 7). ICT integration is a flexible, dynamic and changeable process. ICT integration is accepted as "to contribute students' learning-teaching processes with a suitable ICT and make it permanent and sustainable" (Usluel \& Y1ld1z, 2012).

ICT in education is a domain in which many components (university, faculty, department and faculty members) play a role. Each of these components has unique policies which might affect ICT integration process. ICT integration is the interactional output of these components. It covers both administrative and instructional level interactions. ICT integration process can be examined both from the university perspective and from the perceptions of individuals. Interactive integration works best when the interaction is bidirectional from top down and bottom up. In order to perform effective and efficient ICT integration process, there must be a coordination unit which could function in two-way interaction with university, faculty, department and individuals. In this top down and bottom up integration model, mainly top down integration imply the administrative system and infrastructure, policies etc.; in the bottom up, on the other hand, the instructional issues are addressed. In order to benefit from this model effectively and efficiently, the objectives and implications should go hand in hand. (Altun, Kalaycı, \& Avci, 2011)

\section{Integration of ICT in teacher training program}

The impact of ICT is felt by those teachers who are in use but in the long run it is going to be used by all the teachers for effective teaching learning process. One of the objectives laid down by the NCTE in its "Curriculum Framework for Quality Education" (1998) is to develop communication skills and use modern information technology for school purposes. Guoyuan, Sang, Martin, Johan, Jotondeur and Chang (2010) found that classroom use of ICT directly 
depends on teachers' computer motivation and the supportive use of ICT. Teacher's constructivist beliefs, their attitudes towards computers in education and perceptions about the ICT related school policy influence ICT integration in and indirect way. An indirect relationship was found between teachers' constructivist beliefs and their level of ICT integration.

The Ministry of Human Resource Development (MHRD) undertook several long-term strategies to ensure spread, development and optimisation of ICT tools in Indian classrooms, integrating them with traditional frameworks of knowledge-dissemination. As per the NCTE norms incorporation of ICT in TTIs is made mandatory. To ensure the fulfilment of integration of ICT in TTIs there is a need for critical analysis in relation to;

1) Infrastructure

2) Administration work

3) Curriculum transaction

4) Teachers competency

5) Capacity-building

6) Maintenance facility

7) Evaluation

8) Research activity

\section{Infrastructural facility}

The quality of ICT resources vary depending upon the nature of equipments procured and the location of TTIs (rural or urban area). Taner Altun (2007) points out certain vital factors; ICT infrastructure and physical resources, curriculum and policy development, training lecturers and pedagogical training of teachers in ICT. ICT has the potential to contribute to the improving of students' critical thinking, decision making, problem-solving skills and generating ideas with its integration into classroom activities. The teacher's role at this point is crucial.

Since 2000, it became mandatory for all TTIs in India to fulfil certain essential criteria with respect to land, building (classrooms, laboratories, etc) as per the specification of NCTE norms. The existence of the infrastructural facilities has to be furnished with documentary evidence in the form of both hard and soft copies. The role of ICT automatically comes into force for storage, retrieving and disseminating information either to the affiliating or recognition authority. TTIs incorporated ICT resources in the form of hardware or software or e-content. Necessary ICT equipments are installed for necessary fulfilment of the criteria.

There is a lack of computers and computer-related resources such as printers, projectors, scanners, etc. mostly amongst TTIs in rural areas. The ratio of computer per student is insufficient. There is a mismatch between the complementing resources and inappropriate combination of ICT resources result into reduced diffusion of technology as well as poor ICT understanding in the TTIs. Yuksel, Soner and Zahide (2009) studied on "Main barriers and possible enablers of ICT integration into pre-service teacher education programs". Results are obtained that the majority of the stake-holders believe that lack of in-service training, lack of appropriate software and materials and lack of hardware are the main barriers for integrating ICTs in preservice teacher education programs

\section{Administration work}

Right from the recruitment of faculty and staff, the administration has to keep all records of staffing procedure and other administrative activities. Admission procedure of student trainees in the present times has changed and procedural compared to a few years back. Be it recruitment or admission of student trainees, every aspect of the activity need to be displayed in TTIs own website, communicated to the affiliated University and recognition authority. In 2016 NCTE introduced GIS (Geographical Information System) for identification of location of the institutions; Fire emergency services; QCI (Quality Council of India), National Accreditation Board for Education and Training (NABET) in connection with E-monitoring; GAIRSAIN (2016); Performance Appraisal Record (PAR); Composite structure; Integrated structure. For all such dissemination of information the mode of communication is through ICT only.

As per NCTE regulation, 2014 following tasks are mandatory for every institute.

- Application formalities for new courses

- Inspection formalities from time to time

- Land related documents issued by appropriate authorities

- Building documents duly signed by appropriate authorities in specified format

- Faculty should be of 16 numbers with specified appropriate scale

- Requisite number of non-teaching staff

- Minimum 3000 number of course related titled books

- ICT facilities along with installation of website

- Language, Mathematics, Science, Geography, Psychology, Technology laboratories

- Yoga, Art \& Craft, Boys \& Girls common room, canteen, and parking shed, etc.

- TTIs need to be composite and integrated one within a limited time frame

- Existence of emergency services like fire, e-monitoring, Geographical Information System (GIS)

- Implementation of 2 Years D.El.Ed./B.Ed./M.Ed. Program

In addition, norms and conditions assigned by the Affiliated University has to be taken care of such as;

a) Affiliation Inspection formalities

b) Eligibility fees

c) Examination fees

d) Specified Infrastructural facilities

\section{Curriculum transaction}

The prime task of any TTIs is curriculum transaction. Integrating ICT into curriculum and pedagogy, the role of teachers has been argued to be crucial as the 'agents' of change (OECD 2001; Semenov 2005). The focus is on teaching practices, learning experiences, and the curriculum through integration of ICT. As stated by OECD (2000, p. 16) "teachers must have a range of technical and 
pedagogical skills, with continuous up-dating to match advances in the technology and modes of use." Thus, teachers who use ICT in class have more duty; mastering their content subject, learning and always updating their technological skills. Wanjala, Elizabeth. K and Mukwa (2011) found that few teachers are using ICTs to manage the classroom and to integrate technology into several content areas.

Emphasis is on teacher-centered curriculum (teacher telling) to student centered curriculum (knowledge construction). Be it foundational paper or method subject the benefits of ICT have to make use of. Integrating the technology across the curriculum teacher educators will definitely broaden the horizons of students. ICT offers access to multiple resources and multiple activities that will not only bring in change in the teaching styles but also the learning styles among the students. Use of ICT builds in collaborative approach among the users.

In collaborative-based instruction, teachers teach lessons and then distribute learning assignments based on students' academic skills. All the students learn the same topic as per their individual ability, the nature of assignments varies. Teachers collectively organize students into heterogeneous learning teams by grouping based on learning abilities. After students have read and identified the assignment, they discuss the topic with their group members, share their knowledge, and complete the lesson as a whole group using ICT.

Government of India (GoI) under the department of Electronics and Telecommunication, Ministry of communication and Information Technology launched many programs like: National Knowledge Network (NKN) an initiative of MHRD, State Wide Area Network (SWAN), National Informatics Centre Network (NICNET) and National Fiber Optical Network (NFON) to provide high bandwidth internet connection to all the parts of the country. National Mission on Education through Information communication Technology (NMEICT): NMEICT has been envisaged as a centrally sponsored scheme to leverage the potential of ICT, in teaching and learning process for the benefit of all the learners in higher education institutions in any time any where mode. The mission has two major components:

a) Providing connectivity along with provision for access device and

b) Content generation.

It also seeks to bridge the digital gap in the skill to use computing devices for the purpose of teaching and learning.

UGC Model Curriculum (2001) acknowledges that newest technologies such as Internet, Telemetric, World Wide Web, E-mail, E-Commerce etc. are imparting education.

Digital India: Digital India campaign launched by prime minister of India with objective to transform India into a digitally empowered society and knowledge economy may increase the telecommunication infrastructure in the country and hence Internet users will increase and bridge digital gap in between rural area and urban area. It is an umbrella program covering many departments; the program pulls many existing schemes. Vision on digital India centered on three key areas: Digital Infrastructure to every citizen of India, Governance and services on Demand, Digital Empowerment of citizens. The Government of India Programme launched as "Digital India Week" on 1st of July, 2015. The vision of Digital India is centred on three key areas -
a) Digital Infrastructure as a Utility to Every Citizen
b) Governance \& Services on Demand and
c) Digital Empowerment of Citizens

The results obtained from a study conducted by Visvanathan (2010) revealed that educator pedagogies were the highest predictors on the use of computers in the classroom. Including the use of computers in educator training programs is important so that pre-service educators can see the benefits of using the computer in their own teaching.

\section{Teachers Competency}

In the traditional approach, learning is considered as transmission of knowledge to students performed solely by the teacher whereas in the constructivist approach, learning as authentic and learner centred as put forward by Voogt (2003). As there is a pedagogical shift towards constructivist approach, ICT is of immense use in designing, simulating and offer individualised learning environments for the students.

Voogt (2003) differentiated between traditional learning setting and constructivist approaches. The former considers learning as transmission of knowledge to students, which is the sole responsibility of the teacher. On the other hand, the constructivist approach considers learning as authentic and learner centred. ICT, the computer for example is a great help in the constructivist approach, where one can design simulated and individualized learning environments to students. ICTs are exerting impacts on pedagogical approaches in the classrooms. Their contribution to changes in teaching practices, school innovation, and community services is considerable.

Teacher educators' role in the present day has taken the place that of a facilitator. Rachmawati and Johancynthia (2010) indicates that ICT based learning the role of teachers were significantly changed from transferring of knowledge into facilitating of learning, from a main source person to be a manager of learning. "Faculty Development is both a comprehensive term that covers a wide range of activities ultimately designed to improve student learning, and a less broad term that describes a purposeful attempt to help faculty improve their competence as teachers and scholars" (Eble \& McKeachie, 1985). Mere installation of ICT in the TTIs does not necessarily transform teachers' habitual practices. For facilitating pedagogical practices by the teachers' requires the use of ICT and the manner in which teachers use ICT will result in students performance. Innovation in teaching is essential and this is possible with the use of ICT as pedagogical tools such as electronic 
whiteboards, overhead and LCD projectors. Innovative teachers search information from a variety of resources and make the presentations attractive and lively. Every teacher should know how to use technology, pedagogy and subject area content effectively in their daily classroom teaching. One must ensure technological integration. Chen (2008) argues that a teacher is a crucial factor in making teaching and learning interesting and purposeful and in successfully integrating ICT into classrooms.

A number of teacher educators are integrating ICT in their pedagogical practices, particularly using data projectors and interactive whiteboards in TTIs. The speed and extent of this development can vary between teachers depending on their degree of confidence and competence with these digital technologies. ICT provides online interaction facility. Students and teachers can exchange their ideas and views, and get clarification on any topic from different experts, practitioners, etc. Yuksel, Soner and Zahide (2009) conducted to examine the "Teacher educators" ICT competencies, usage, and perceptions". The data were collected from 111 teachers and interviewing with 6 teachers. The results indicated that most of the participants expressed positive perceptions about the integration of ICT into teacher education programs. Generally, their ICT competency was completely sufficient. They use the Internet as a supportive tool to their courses, and particularly search engines used by them.

Schneckenberg (2010) writes the "faculty is nowadays facing new pedagogical challenges; they have to design learning environments which respond to the changing needs of technology-savvy students; and they have to integrate ICT into their courses to extend the flexibility of educational services in universities".

A major obstacle in the use of ICT in TTIs is the lack of knowledge and skills. Only handful teachers make use of ICT in pedagogical practices. Most of the teachers are unaware and rigid and not willing to adapt to the change. They are sceptical about the effectiveness and utility of ICTs. For successful functioning of ICT in TTIs teachers need to collaborate with other teachers as well as learn how to use hardware and software and at the same time keep oneself updated with the latest technology. Teachers need to be competent enough to employ particular applications and be proficient with computers, be confident to integrate ICT into existing curricula, and employ information technologyoriented practices during impart of pedagogical contents.

\section{Capacity-building}

ICT refers to those technologies that ascertain the efficiency and effectiveness for communication and the devices that assist in handling information. Capacity building of inservice teachers has been the key to the widespread infusion of ICT enabled practices in schools. Teachers were to be provided Induction Training and Refresher Courses. The Induction trainings were to be imported by the Regional Institute of Education, National Councils of Educational Research and Training (NCERT), State Councils of Educational Research and Training (SCERT). Capacity building through pre service teacher education, nowadays are suitably trained and oriented to use ICT in their training programs. National Council for Teacher Education (NCTE) has laid down guideline about availability of ICT infrastructure in each of the training institutes. NCTE prescribed curriculum in ICT to be revised periodically, for such teachers. Capacity building of teacher educators is crucial in establishment and optimal utilization of ICT is essential in the teacher education training programs. Models of ICT infrastructure, build, own, operate, and transfer (BOOT) models is to be preferred using services such as equipments manpower, software are to be tried out and appropriate combination, based on feasibility and cost effectiveness need to be adopted.

\section{Maintenance}

The materialization of ICTs needs to be thought of. Administration and Teachers most often use ICTs for 'routine tasks' and the information are stored and recorded for future use in various forms (hard disks, memory storage, pen drive or $\mathrm{CD}$ ). The ICT equipments are in continuous use as such these are to be maintained adequately. Maintenance of hardware technology is utmost necessary. The equipments demands for proper care and handling. Certain recurring expenses are no doubt creep in to keep the equipments in working condition at any point of time. For example; installation of antivirus in the laptop or computer is of great importance so that no problems occur. The longevity of the equipments very much depends on the effort put on the maintenance factor.

\section{Evaluation}

Evaluation process is another crucial function in the entire educational process. The future of the students rests upon the output out of evaluation. Baker (1999) emphasizing technology that besides a means to collect, interpret, and document findings, evaluation is a planning tool that should be considered at the beginning of any technology Innovation. She adds that the overall focus of evaluation is student learning.

Evaluative information is able to be retrieved through ICT in context to percentage of pass, absenteeism, financial resources, budgets, etc. Evaluation brings in change if learning goals are not met.

\section{Research activity}

A variety of ICT products and services are helpful for research work in exploration of quick information and assists in the research to access, manage, integrate evaluate, create and communication easily.

Kmalanayan (2008) pointed out that information technology in education is created the need for all teacher education faculties to be proficient in the use and integration of ICT into mainstream teacher education programme delivery. Integrating ICT tools into the curriculum and tailoring pedagogy according to the social environment are necessary for achieving qualitative improvements in learning (Kremer and Holla 2008; Sreekumar and Sanchez 2008; Barret (2009); Gurumurthy 2009).

ICTs have the potential to drive innovative and effective ways of teaching-learning and research. The inclusion of learning tools, easier use of multimedia or simulation tools, 
easy and almost instant access to data and information in a digital form which allows for computations and data processing generates possibilities which were otherwise not feasible.

\section{Innovation in Teacher Education Program}

Diverse role of ICT in education is in use for digital literacy and developing all kinds of resources. ICT is playing a direct role in the field of education. ICT is in use in schools, educational institutions and the community. Proper utilisation of ICTs helps in enhancing quality education. ICT performs pedagogical, cultural, social, professional and administrative roles in an institution. ICTs have an important role to play in changing and modernizing educational systems and ways of innovation in teaching learning process. Traditional teaching methodology is practiced by most of the teachers; still ICT has to be applied in teaching process. Teachers without ICT knowledge have to acquire digital age literacy skills, use technology for acquiring information, solving problems, sharing knowledge, and creating innovative ideas. Future teachers are imparted training with effective use of information and communication technologies (ICT) in the teacher education curriculum. Two aims of teacher training are fundamental: teacher education in ICT; and teacher education through ICT. The application of ICT in the education setting has to be cultivated, promoted and nurtured as new interactive relationships among teachers, learners and technologies are in high demand. It is high time for the teachers to acquire mastery over the technical knowhow or else the teachers have to face unwanted problems. Guoyuan, Martin, Johan and Jotondeur (2009) found that "successful ICT integration is clearly related to the thinking processes of classroom teachers, such as teacher beliefs, teacher efficacies, and teacher attitudes toward ICT. The results underpin the importance of an integrated and concurrent understanding of teachers thinking process. They also suggest that in order to improve the innovation of classroom activities, teachers thinking processes should be challenged". In the era of Innovations and Technological advancements, it is the teacher, who should ensure the innovative teaching strategies in enhancing quality based education. Teacher education system is an important vehicle for improving quality-based education system. Bangou (2006) explains, in turn, the importance of ICT and their integration into the teaching process, yet he stressed the urgency of training ICT teachers, so that they could use them effectively in their teaching/training function.

There is a need for developing ICT skills among the teachers. Benkler (2006) proposed 20 skills that the teacher has to develop they are as follows 1 . Word processing skills; 2. Spread sheet skill; 3. Data base skill; 4. Electronic presentation; 5. Web navigation; 6. Web site design; 7. Skill of using digital camera; 8. E-mail management; 9. Computer Network knowledge applicable to teacher education system; 10. File management \& windows explorer skills; 11. Downloading software from the web (knowledge including e Books; 12. Installing computer software onto a computer system; 13. Web ICT or blackboard teaching skills; 14. Video conferencing skills; 15. Computer-related storage devices; 16. Scanner knowledge; 17. Knowledge of PDAs;
18. Deep web knowledge; 19. Educational copy right knowledge; 20. Computer security knowledge.

At the same time it also needs to be pointed out the ICT Skills \& Competencies to be developed in Student Teachers:

1) Internet Surfing for identifying various sources for the development of lesson Plans.

2) Using different computer applications like multimedia, word processing database, spreadsheet, power point, desktop publishing and Internet/telecommunications assignments, projects, etc. has to be formulated.

3) Using the Internet on line participation for professional development workshops and seminars has to be worked out.

4) For efficient managing learning student has to apply data management tools.

5) Using Excel and Access database management a variety of information can be collected, organised for report writing purpose.

6) Evaluating and selecting appropriate Software for a particular subject as per Student needs.

7) Using interactive technologies, e-learning, blended learning, collaborative-co-operative learning, mLearning, etc. to be applied in the classroom by the teachers to provide students with access to such technologies and guidance in using them in a way that will enhance their learning.

Education in India is the joint contribution of both government and private sectors educational institutions. Teacher Education institutions are one such educational institutions affiliated to Universities/State Education Department recognised by an apex body National Council for Teacher Education (NCTE). The National Council for Teacher Education Act, 1993, which came into force on 1st July, 1995, provided for "the establishment of the National Council for Teacher Education with a view to achieving planned and coordinated development of the teacher education system throughout the country, the regulation and proper maintenance of norms and standards in the teacher education system and for matters connected herewith". Responsibility for imparting training to the pre or in service secondary school teachers rests on the teachers training institutions (TTI). All over India B.Ed. (Bachelor of Education) training is imparted in colleges. During 80s and before training used to be the look out of the respective states only. Affiliated University used to frame syllabus based on which training was imparted. Classes used to be held mostly during evening hours in majority of the colleges. There was not much restriction with regard to the admission of number of candidates possessing degree qualification. Part-time teacher educators were recruited mostly with a meagre salary. With the passage of time strict rules and regulations are enforced all over India in order to bring in uniformity and quality in training. This is really appreciable step undertaken.

The demand for secondary teachers has been quite high since the post-independence period. Only a limited number of government TTIs were set up which were unable to fulfil the pressing need of large number of trained teachers. Alternative way came into being through establishment of 
private TTIs. In the last 70 years this mode of imparting training has been the trend. B.ED. course was for one year duration only all these years throughout India. After, 2015, duration for B.ED. course is extended to two years. Along with the structural changes in the teacher training programs, changes are noticeable with respect to curriculum also. A variety of subjects of study like ICT, Action Research, and so on are included due to its immense demand and importance in this competitive world.

The National Policy on Information and Communication Technology (ICT) in School Education "aims at preparing youth to participate creatively in the establishment, sustenance and growth of a knowledge society leading to all round socio-economic development of the nation and global competitiveness". Dash (2007) in a study found that Information and Communication Technology is an important instrument that can transfer the present isolated, teacher centered and book centered learning environment into a student centered environment, and states that ICT can change the traditional concept of learning process. ICT helps in the professional development of teaching and learning and individuals involved in the programs of teacher education. It can be infuse in the learning process so as to acquire the knowledge and skill efficiency. ICT provides access to resources so that teachers, can apply new knowledge and skills they have learnt. Communication technology will be able to develop the capacity of the teacher and teacher educator and at the same time can strengthen the capacity of teacher educator, which is the fundamental requirement of effective transactional strategy. Massive Open Online Courses (MOOCs) platform popularly known as SWAYAM (Study Webs of Active learning for Young Aspiring Minds) launched by MHRD, GoI on 9th July, 2017 aimed to take the best teaching learning resources to all, including the most disadvantaged. SWAYAM seeks to bridge the digital divide for students who have hitherto remained untouched by the digital revolution and have not been able to join the mainstream of the knowledge economy. The SWAYAM portal is offering online courses for students, teachers and teacher educator from school education and higher education to promote quality education and lifelong learning.

\section{Conclusion}

Integration of ICT in pedagogy is not only essential in curriculum transaction at the same time the need for technology in infrastructural development, administrative and maintenance activities merits due priority. For successful and productive transaction of curriculum according to the demands of the present day pedagogical process the factors such as teachers competency, capacitybuilding, evaluation and research activity are equally important with the application of ICT resources. Knowledge development during pre-service training has gained much importance with the notion that exposure to ICT during this time is helpful in increasing student teachers' willingness to integrate technology with classroom teaching. Both integration and innovative use of ICT will have a boosting impact on the teacher education program.

\section{References}

[1] Altun, S. A., Kalayci, E., \& Avci, Ü. (2011) Integrating ICT at the Faculty level: A Case Study. The Turkish Online Journal of Educational Technology, 10 (4), 230-240.

[2] Altun, Taner (2007) "ICT in Intial Teacher Education", Journal of Turkish Science Education Volume 4, Issue 2, $1-16$

[3] Bangou, F. (2006) Tice Integration and Teaching Learning: A Systems Approach, Alsic [Online], 9 2006, available at: alsic_v09_10-pra2, posted online 30 November 2006, Accessed 27 December 2018. URL: http://journals.openedition.org/alsic/290; DOI: 10.4000 / alsic. 290

[4] Brannigan, N. (2010). Enhancing leadership capacity in ICTs in education through technology enabled collaboration, pedagogy for technology enhanced learning, The Turkish Online Journal of Educational Technology - TOJET ISSN: 1303-6521 7 (4) 9-89.

[5] Chen, C. (2008) "Why do teachers not practice what they believe regarding technology integration," The Journal of Educational Research, vol. 102, no. 1, pp. 6575 .

[6] Earle, R.S. (2002). The integration of instructional technology into public education: Promises and challenges. Educational Technology, 42(1): 5-13. [Google Scholar]

[7] Eble, K. E., \& McKeachie, W. (1985). Improving undergraduate education through faculty development. San Francisco, CA: Jossey-Bass.

[8] Guoyuan, Sang (2010). "Teacher Characteristics and ICT Integration: A Study in Preservice and In-service Primary Education Teachers in China", www.osun.org

[9] Guoyuan Sang, Martin Valcke, Johan van braak, Jotondeur \& Chang Zhu. (2010). "Predicting ICT Integration into Classroom Teaching in Chinese Primary Schools: Exploring the Complex Interplay of Teacher- Related Variables", Journal of Computer Assisted Learning, Blackwell publishing Ltd.

[10] Hota, Geeta (2015) Information Communication Technology (ICT) in Education: A Government of India (GoI) Initiative. International Journal of Recent Advances in Engineering \& Technology (IJRAET) ISSN (Online): 2347 - 2812, Volume-3, Issue -12.

[11] Leven, T. and Wadmany, R (2008) cited in Shahmir, Samieh; Hamidib, Farideh; Bagherzadehc , Zohre; and Salami, Leila Role of ICT in the Curriculum Educational System . Procedia Computer Science 3 (2011) 623-626

[12] Mishra, P., \& Koehler, M. (2006). Technological pedagogical content knowledge: A framework for teacher knowledge. Teachers College Record, 108(6), 1017-1054

[13] Muttaiah, Vemula (2013 ) Role of Computer Education Programme in Teacher Education Institutions of Kakatiya University-an analytical study. BEST: International Journal of Humanities, Arts, Medicine and Sciences (BEST: IJHAMS) Vol. 1, Issue 1, Oct 2013, $17-22$

[14] National Board of Accreditation (NBA), India, Retrieved from -www.nbaind.org 
[15] National Council for Teacher Education. (2010). National Curriculum Framework for Teacher Education. New Delhi: NCTE

[16] National Policy on ICT in School Education (2008). Ministry of Human Resource Development. Government of India. www.education.nic.in

[17] Organization for Economic Cooperation and Development (2001) Learning to change: ICT in schools. Paris: OECD

[18] OECD, (2001). Learning to change: ICT in schools. Paris: Organisation for Economic Co-operation and Development

[19] Okorafor, A. O. \& Okorafor, P. N. (2011) Pedagogical use of ICT in Science Education: the Constructivist Persperctive. Journal of Research in Science and Technology Education vol. 4 No. 1 pp. 128-137; November 2011 ISSN: 1115-6783

[20] Pelgrum, W. J. (2001). Obstacles to the integration of ICT in education: results from a worldwide educational assessment. Computers \& Education, 37(2), 163-178. doi: 10.1016/S0360-1315(01)00045-8

[21] Rachmawati.Y, and Johan Cynthia.R. (2010). "Information and Communication Technology (ICT) Based Learning in Teaching Secondary School in Indonesia" Proceedings of the 1st UP1 International Conference on Technical and Vocational Education and Training, Bandung, Indonesia, 10-11 November.

[22] Schneckenberg, D. (2010). Overcoming barriers for eLearning in universities - portfolio models for eCompetence development of faculty_1046 979..991. British Journal of Educational Technology, 41 (6), 979991.

[23] Semenov, A. (2005). Information and communication technologies in schools: A handbook for teachers or How ICT can create new, open learning environments, UNESCO.

http://unesdoc.unesco.org/images/0013/001390/139028 e.pdf.

[24] Tok, Reena and Sora, Marpe (2013) Perspective of Emerging Integrating Technology (ICT) in Learning and Teaching Boa. International Journal of Information and Education Technology, Vol. 3, No. 2, April 2013

[25] Visvanathan Naicker (2010). "Educator"s Pedagogy Influencing the Effective Use of Computers for Teaching Purposes in Classrooms: Lessons learned from Secondary Schools in South Africa", Educational Research and Review Vol. 5(11), 674-689, Available online at http://www.academicjournals.org/ERR2 ISSN 1990-3839 @Academic Journals.

[26] Voogt, J. (2003). Consequences of ICT for aims, contents, processes, and environments of learning. In J.van den Akker, W. Kuiper \& U. Hameyer (Eds.), Curriculum landscapes and trends (pp 217 -236). Dordrecht: Kluwer Academic Publishers. Watson, D.M. (2001). Pedagogy before Technology: Re-thinking the Relationship between ICT and Teaching. Education and Information Technologies, 6, 4, 251-266.

[27] Wanjala Martin, M. S.; Elizabeth N.Khaemba \& Mukwa Chris. (2011). "Significant Factors in Professional Staff Development for the Implementation of ICT Education in Secondary Schools: A case of schools in Bungoma District, Kenya", International journal of Curriculum and Instruction Vol. April,1(1), 30-42.

[28] Yuksel, Goktas; Soner, Yildiram \& Zahide, Yildrim.(2009) "Main Barriers and Possible Enablers of ICT Integration into Pre-service Teacher Education Programs", Educational Technology and Society, 12(1), 193-204

- $\quad$ http://pixel.cs.vt.edu/edu/fis/techcons.html

- http://thejournal.com/articles/17325

- http://www.col.org/barriers.html

[29] Web source http://digitalindia.org/

[30] https://shodhganga.inflibnet.ac.in/handle/10603/272792 9 Oct 2014 